\title{
PROCEEDINGS OF THE
}

PREHISTORIC

\section{SOCIETY}

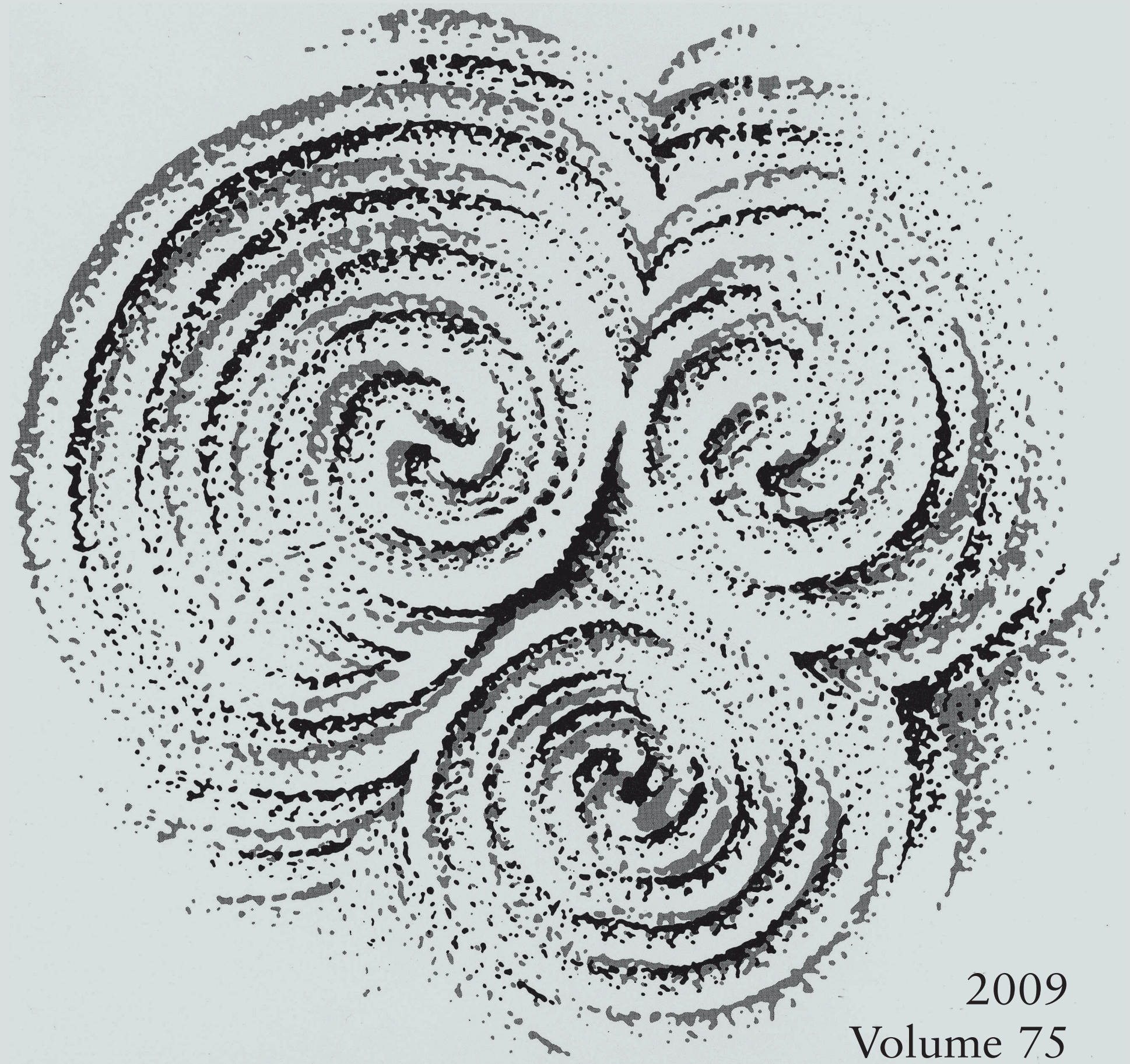




\section{THE PREHISTORIC SOCIETY}

THE SOCIETY promotes interest in prehistoric archaeology, encourages and engages in research, and disseminates knowledge of prehistory. Meetings are held in London between October to March, with a full programme of lectures at other centres around the country. Other activities include conferences, field excursions and study tours, the last held both in Britain and abroad. The Proceedings are published annually.

MEMBERSHIP. Applications for membership, subscriptions and changes of address should be sent to the Membership Secretary, The Prehistoric Society, University College London, Institute of Archaeology, 31-34 Gordon Square, London WC1H OPY, England. Subscriptions are due on 1 January.

SUBSCRIPTION RATES:

$\begin{array}{ll}\text { Individual } & £ 35 \\ \text { Institutional } & £ 50 \\ \text { Joint } & £ 40 \\ \text { Student } & £ 17.50 \\ \text { Retired, receiving Proceedings } & £ 25 \\ \text { Retired, not receiving Proceedings } & £ 12.50\end{array}$

PROCEEDINGS. All communications concerning the publication of papers and notes in the Proceedings should be sent to Dr Julie Gardiner, Wessex Archaeology, Portway House, Old Sarum Park, Salisbury SP4 6EB, England, j.gardiner@wessexarch.co.uk. All contributors are encouraged to consult the Editor at an early stage in the preparation of papers and to obtain detailed instructions to contributors.

Books for review and periodicals for exchange should be sent to the Reviews Editor, Dr M. Allen, AEA: Allen Environmental Archaeology, Redroof, Green Road, Codford BA12 ONW, UK

Communications on other matters such as back numbers (see inside back cover for details), the insertion of leaflets, non-receipt of the Proceedings and permission to reproduce illustrative material from the Proceedings should be addressed to the Administrative Assistant (address below).

COPYRIGHT in the Proceedings rest with the Society. The Society will permit, without the need for specific authorization or payment of a fee, photocopying of

i. single copies of individual papers or sections of the Proceedings for the private use of individual researchers;

ii. single copies of individual papers or section of the Proceedings for library reserve or short-term loan use;

iii. multiple copies of individual papers or sections of the Proceedings for teaching use, provided that such copies are taken for a non-profit-making institution for educational use within that institution only.

This consent does not extend to copying for general distribution, advertising or promotional purposes, the creation of new collective works, or resale.

RESEARCH FUND. The Society hopes to make one or more awards from the Research Fund in 2003. Applications will be considered from members carrying out research into prehistoric archaeology anywhere in the world. Application forms are available from the Administrative Assistant, The Prehistoric Society, University College London, Institute of Archaeology, 31-34 Gordon Square, London WC1H 0PY, England email: prehistoric@ucl.ac.uk. The closing date for applications for 2008 is 1 January 2008.

PUBLICATION GRANTS. All papers submitted to the Proceedings are considered entirely on merit but all authors are encouraged to seek funding wherever possible to help offset the cost of production.

The views expressed by the authors are not necessarily those of the Editor or Society.

The Prehistoric Society Website is : http://www.prehistoricsociety.org 


\title{
PROCEEDINGS OF THE PREHISTORIC SOCIETY VOLUME 75
}

\author{
EDITED BY \\ JULIE GARDINER, B.A., Ph.D., F.S.A., M.I.F.A. \\ Wessex Archaeology \\ Salisbury \\ EDITORIAL ADVISORY COMMITTEE \\ M. Aldhouse-GreEN \\ N. ASHTON \\ G. BARKER \\ T. CHAMPION \\ G. COONEY \\ J. CHAPMAN \\ A. DAVID \\ C. FRENCH \\ C. Gosden \\ F. HeALY \\ A. SAVILle \\ A. SHERIDAN \\ G. J. WAINWRIGHT \\ THE PREHISTORIC SOCIETY
}


President

Vice-Presidents

Secretary

Treasurer

Editor

Editor, Newsletter

Editor Reviews

Conservation Co-ordinator

Meetings Secretary

Membership Secretary/ Administrative Assistant

Council
C. L. N. RugGles, M.A., D.Phil., F.S.A.

J. C. Chapman, B.A., Ph.D

N. Sharples, B.A., F.S.A.Scot.

A. SHERIDAN, B.A., M.A., Ph.D., F.S.A.Scot., A.I.F.A

P. TOPPING, B.A., M.I.F.A.

J. POllard, B.A., Ph.D.

A. AINSWORTH, B.A., A.C.M.A

J. P. GARDINER, B.A., Ph.D., F.S.A., M.I.F.A.

J. BRUCK, M.A., Ph.D.

M. J. Allen, B.Sc., Ph.D., M.I.F.A., F.L.S., F.S.A.

R. JOHNSTON, B.A., Ph.D.

J. LAST, B.A., Ph.D.

T. C. S. MACHLING, B.A., Ph.D.

J. COTTON, B.A., M.A., F.S.A.

V. EDWARDS, B.A.

D. FIELD, Ph.D., F.S.A., F.S.A.Scot

H. FoKkens, Prof. Dr, M.A., Ph.D.

D. GARROW, B.A., M.A., Ph.D.

G. HEY, B.A., Ph.D., F.S.A., M.I.F.A.

A.T.O. LANG, B.A., M.Phil.

N. MilneR, B.A., Ph.D., F.S.A.Scot

J. NOWAKOWSKI, B.A., F.S.A., M.I.F.A.

R. Pope, B.A., M.A., Ph.D., F.S.A.Scot

J. SIDDELL, Ph.D.

F. STURT, B.A., M.A., Ph.D.

G. WARREN, B.A., M.A., Ph.D., F.S.A.Scot

E. WILKES, B.Sc., M.A., Ph.D., PiFA

PRINTED IN GREAT BRITAIN

BY DERRY PRINT LIMITED

GLAISDALE PARKWAY, BILBOROUGH

NOTTINGHAM NG8 4JQ 


\section{CONTENTS VOL. 75, 2009}

1. Landscape Archaeology in Central Europe. By A. Zimmermann, K.P. Wendt, T. Frank, and J. HILPERT

Page 1

2. A Race Apart: Insularity and Connectivity. By BARRY CUNLIFFE

Page 55

3. Genuine Diversity? The Broom Biface Assemblage. By RoBERT Hosfield and JENNIFER CHAMBERS

Page 65

4. A New Bayesian Chronology for Mesolithic Occupation at Mount Sandel, Northern Ireland. By Alex BAYLISS and PeTER WOODMAN

Page 101

5. A Revision of Corded Ware Settlement Pattern - New Results from the Central European Low Mountain Range. By Johannes Müller, Timo Seregély, Cornelia Becker, Anne-Mette Christensen, Markus Fuchs, Helmut Kroll, Doris MischKa, and ULRICH SCHÜSSLER

6. Esoteric Knowledge? Ancient Bronze Artefacts from Iron Age Contexts. By RiCHARD HINGLEY

7. Investigation of a Final Palaeolithic Site at Rookery Farm, Great Wilbraham, Cambridgeshire. By Chantal Conneller

8. Excavations at Politiko Kokkinorotsos. A Chalcolithic hunting station in Cyprus. By Jennifer M. Webb, David Frankel, Paul Croft, and Carole McCartney

Page 189

9. The Valdoe: archaeology of a locality within the Boxgrove palaeolandscape. By MATTHEW Pope, Mark Roberts, ANDrew Maxted, and Pat Jones

Page 239

10. A Late Neolithic Palisaded Enclosure at Marne Barracks, Catterick, North Yorkshire. By Duncan Hale, Andy Platell, and Andrew Millard

Page 265

11. Pyhtää Susikopinharju (1), Finland: a Site with Mesolithic Dwellings. By KenNETH K.A. LÖNNQVIST

Page 305

12. The V-bored buttons of Great Britain \& Ireland, By IAN A.G. SHEPHERD

Page 335

French, German, and Spanish abstracts

Page 371 